\title{
Factors associated with the decrease in hepatitis B surface antigen titers following interferon therapy in patients with chronic hepatitis B: Is interferon and adefovir combination therapy effective?
}

\author{
YOSHIHIKO YANO ${ }^{1,2}$, YASUSHI SEO ${ }^{3}$, HIROKI HAYASHI ${ }^{2}$, YURI HATAZAWA ${ }^{2}$, HIROTAKA HIRANO ${ }^{2}$, \\ AKIHIRO MINAMI $^{2}$, YUKI KAWANO ${ }^{2}$, MASAYA SAITO ${ }^{4}$, TOSHIAKI NINOMIYA ${ }^{5}$, MASAHIKO SUGANO $^{6}$, \\ HAJIME YAMADA $^{7}$, NAOTO KITAJIMA ${ }^{8}$, SEITETSU YOON ${ }^{9}$ and YOSHITAKE HAYASHI ${ }^{2}$ \\ ${ }^{1}$ Center for Infectious Diseases; ${ }^{2}$ Department of Gastroenterology, Kobe University Graduate School of Medicine, \\ Kobe 650-0017; ${ }^{3}$ Seo Clinic, Himeji 672-8002; ${ }^{4}$ Saito Internal Clinic, Kobe 651-2412; ${ }^{5}$ Ninomiya Internal Clinic, \\ Itami 664-0856; ${ }^{6}$ Sugano Naika Clinic, Himeji 671-0223; ${ }^{7}$ Department of Gastroenterology, Shinko Hospital, \\ Kobe 651-0072; ${ }^{8}$ Department of Gastroenterology, Kasai City Hospital, Kasai 675-2393; ${ }^{9}$ Department of \\ Gastroenterology, Kakogawa Municipal Hospital, Kakogawa 675-8555, Japan
}

Received June 30, 2017; Accepted July 15, 2017

DOI: $10.3892 /$ br.2017.944

\begin{abstract}
The purpose of antiviral therapy in chronic hepatitis $\mathrm{B}(\mathrm{CHB})$ is generally to achieve a decrease and ultimately disappearance of $\mathrm{HBs}$ antigen (HBsAg). Interferon (IFN) therapy of CHB appears to be less effective in Asian countries than in European countries, and the advantage of IFN and nucleotide(s) analog (NA) combination therapy has yet to be fully investigated. The present study focused on the factors associated with a decrease in HBs antigen following IFN monotherapy or IFN + NA combination therapy. A total of 35 patients with CHB who received IFN-based therapy (mean \pm standard deviation age $36.7 \pm 8.5$ years; 27 males and 8 females) were enrolled in this study. Of the 35 patients, 21 patients received pegylated IFN monotherapy and 14 patients received IFN and adefovir (ADV) combination therapy. We examined the factors associated with reductions in the HBsAg titer of $>1.0 \mathrm{log} \mathrm{IU} / \mathrm{ml}$ from the initial $\mathrm{HBsAg}$ titer to the end of treatment and to 24 weeks after treatment. Although 13 patients (37\%) had a reduction in $\mathrm{HBsAg}$ of $>1.0 \mathrm{IU} / \mathrm{ml}$ at the end of treatment, it was only maintained to 24 weeks after treatment in 7 patients $(20 \%)$. The HBV core-related antigen ( $\mathrm{HBcrAg})$ titer before treatment was significantly higher in patients with a decrease in HBsAg at the end of treatment than in patients without a decrease in HBsAg (6.56 \pm 0.78 vs. 5.30 $\pm 1.66 \log \mathrm{IU} / \mathrm{ml}, \mathrm{P}<0.05)$. Moreover,
\end{abstract}

Correspondence to: $\mathrm{Dr}$ Yoshihiko Yano, Department of Gastroenterology, Kobe University Graduate School of Medicine, 7-5-1 Chuo-ku, Kobe 650-0017, Japan

E-mail: yanoyo@med.kobe-u.ac.jp

Key words: hepatitis B virus, interferon, adefovir, HBs antigen, HBcr antigen an increase in alanine aminotransferase (ALT) of $>2$ times from baseline occurred significantly more frequently in patients with a decrease in HBsAg (62 vs. $14 \%, \mathrm{P}<0.05$ ). The proportion of patients with a decrease in HBsAg was significantly greater in patients who received IFN monotherapy than in patients who received IFN and ADV combination therapy (43 vs. 29\%, $\mathrm{P}<0.05)$. The present results revealed that the HBcr antigen titer before therapy and an on-treatment elevation of ALT (indicative of host instruction flare) are important factors associated with a decrease in HBsAg titers after IFN-based therapy. The efficacy of IFN and ADV combination therapy was not apparent in terms of a reduction in the HBsAg titer.

\section{Introduction}

Hepatitis B virus (HBV) infection is a major health problem, with approximately 350 million individuals having chronic infection and approximately 600,000 hepatitis B-related deaths annually. The main purpose of treating chronic hepatitis $\mathrm{B}(\mathrm{CHB})$ is to achieve sustained suppression of HBV replication and to improve quality of life and survival by preventing progression to cirrhosis and liver cancer (1-3). $\mathrm{HBs}$ antigen ( $\mathrm{HBsAg}$ ) is a classical serological marker used to screen for $\mathrm{HBV}$ infection. In recent years, serum $\mathrm{HBsAg}$ titer has been established as a useful marker for monitoring the response to antiviral therapy and is associated with the severity of fibrosis among $\mathrm{HBeAg}$-positive $\mathrm{CHB}$ patients $(4,5)$. Moreover, achieving HBsAg seroclearance is an ultimate aim of antiviral therapy and is related to favorable clinical outcomes of CHB (6).

Currently, nucleotide(s) analogs (NA) and interferon (IFN) are commonly used to treat $\mathrm{CHB}$ (7). Although several kinds of NAs are available, including lamivudine, telbivudine, entecavir, emtricitabine, adefovir dipivoxil (ADV), and tenofovir (8), patients cannot stop treatment because covalently 
Table I. Clinical characteristics of patients before treatment.

\begin{tabular}{lccc}
\hline Variables & IFN monotherapy & IFN + ADV combination & All patients \\
\hline $\mathrm{n}$ & 21 & 14 & 35 \\
Age (years) & $38.2 \pm 8.5$ & $34.4 \pm 8.0$ & $36.7 \pm 8.5$ \\
Sex (M:F) & $16: 5$ & $11: 3$ & $27: 8$ \\
Genotype (A:B:C) & $1: 2: 17$ & $0: 2: 12$ & $1: 5: 29$ \\
HBeAg-positive & $8(38 \%)$ & $12(86 \%)$ & $20(57 \%)$ \\
PLT count $\left(x 10^{4} / \mathrm{mm}^{3}\right)$ & $21.0 \pm 3.8$ & $20.6 \pm 4.1$ & $20.8 \pm 4.0$ \\
AST $(\mathrm{IU} / \mathrm{l})$ & $106.2 \pm 181.1$ & $94.8 \pm 110.7$ & $101.3 \pm 154.7$ \\
ALT $(\mathrm{IU} / \mathrm{l})$ & $158.6 \pm 306.9$ & $115.9 \pm 105.2$ & $141.5 \pm 247.8$ \\
T-Bil $(\mathrm{mg} / \mathrm{dl})$ & $0.80 \pm 0.59$ & $0.72 \pm 0.24$ & $0.77 \pm 0.48$ \\
HBsAg titer $(\log \mathrm{IU} / \mathrm{ml})$ & $3.28 \pm 0.86^{\mathrm{a}}$ & $4.39 \pm 0.69^{\mathrm{a}}$ & $3.72 \pm 0.97$ \\
HBcrAg titer $(\log \mathrm{IU} / \mathrm{ml})$ & $5.20 \pm 1.58^{\mathrm{a}}$ & $6.53 \pm 1.18^{\mathrm{a}}$ & $5.78 \pm 1.04$ \\
HBV-DNA $(\log$ copies/ml) & $6.80 \pm 1.70^{\mathrm{a}}$ & $8.71 \pm 1.39^{\mathrm{a}}$ & $7.53 \pm 1.84$ \\
\hline
\end{tabular}

${ }^{\text {a }}$ <0.01 (Mann-Whitney U-test). IFN, interferon; ADV, adefovir; M, males; F, females; HBeAg, hepatitis B envelope antigen; PLT, platelet; AST, aspartate aminotransferase; ALT, alanine aminotransferase; T-Bil, total bilirubin; HBsAg, hepatitis B surface antigen; HBcrAg, HBV core-related antigen; HBV-DNA, hepatitis B virus DNA.

closed circular (ccc)DNA is stably incorporated into the nucleus of hepatocytes, even after treatment with an NA $(6,8)$. Currently, however, the efficacy of IFN in combination with an NA is not well established and some controversial findings have been published $(9,10)$. It was reported that the combination of pegylated (PEG)-IFNa with lamivudine was associated with a greater virological response during treatment but not after treatment $(11,12)$. A recent study revealed that PEG-IFN in combination with telbivudine (LDF) increased the risk of peripheral neuropathy (13). By contrast, IFN in combination with ADV was effective in terms of reducing intrahepatic cccDNA and reducing the serum HBsAg titer (14-16). Based on this complicated situation, combination therapy is not recommended in the international guidelines proposed by the Asian-Pacific Association, the American Association for the Study of Liver Diseases and the European Association for the Study of the Liver (1-3). However, recent meta-analyses revealed that NA and IFN combination therapy was associated with improved outcomes than NA or IFN monotherapy $(10,17)$. In addition, it is unclear whether the HBsAg titer is decreased by combination therapy.

In the present study, we examined the efficacy of IFN monotherapy, and IFN and ADV combination therapy and the factors associated with a decrease in HBsAg of $>1 \log \mathrm{IU} / \mathrm{ml}$ from baseline.

\section{Materials and methods}

Thirty five patients with CHB who received IFN-based therapy were enrolled in the study (mean \pm standard deviation age, $36.7 \pm 8.5$ years; 27 males and 8 females). Overall, 21 received PEG-IFN monotherapy and 14 received IFN and ADV combination therapy. The decision to use IFN monotherapy or IFN and ADV combination therapy was made by the attending physician. The serum HBsAg titer was determined using an Abbott Architect HBsAg quantative II assay (Abbott Laboratories, Abbott Park, IL, USA). Serum HBV DNA levels were measured using a quantitative PCR assay (Abbott Laboratories). Serum aspartate aminotransferase (AST), alanine aminotransferase (ALT), albumin, and total bilirubin concentrations, and the international normalized ratio (INR) for prothrombin time were measured using standard laboratory procedures. We examined the factors associated with a decrease in the HBsAg titer of $>1.0 \log \mathrm{IU} / \mathrm{ml}$ from baseline to the end of treatment and at 24 weeks after treatment.

The present study was conducted between November 2011 and June 2013 by Kobe University Hospital and three affiliated hospitals in Hyogo prefecture. The study protocol was approved by the Ethics Committee at Kobe University Hospital, and written informed consent was obtained from each patient before starting treatment.

Statistical analysis. Statistical analyses were performed using SPSS v16 software (SPSS Inc., Chicago, IL, USA). P $<0.05$ was considered to indicate a statistically significant difference.

\section{Results}

Serological and virological characteristics of the patients. The patient backgrounds are summarized in Table I. The mean age of the patients was $36.7 \pm 8.5$ years. Overall, 29 patients had genotype $\mathrm{C}$ and 1 patient was genotype A. Twenty patients $(57 \%)$ were positive for $\mathrm{HB}$ envelope antigen $(\mathrm{HBeAg})$. Serum HBsAg, HBcrAg, and HBV-DNA were significantly lower in patients who received IFN monotherapy than in patients who received combination therapy.

HBsAg, HBV-DNA, and ALT levels during and after therapy. The mean HBsAg titer, HBV-DNA level, and ALT level in patients who received IFN monotherapy or combination therapy are shown in Fig. 1. The mean HBsAg titer and HBV-DNA level before therapy were much greater in patients who received combination therapy than in those who received IFN monotherapy. The mean ALT and HBV-DNA levels in 
Table II. Factors associated with a decrease in HBsAg of $>1 \log \mathrm{IU} / \mathrm{ml}$ at the end of treatment.

\begin{tabular}{|c|c|c|c|}
\hline Variables & $\begin{array}{c}\text { Patients with a } \\
\text { decrease in } \mathrm{HBsAg}\end{array}$ & $\begin{array}{l}\text { Patients without a } \\
\text { decrease in } \mathrm{HBsAg}\end{array}$ & P-value \\
\hline $\mathrm{n}$ & $13(37 \%)$ & $22(63 \%)$ & \\
\hline Age (years) & $34.2 \pm 4.7$ & $38.2 \pm 9.83$ & n.s. \\
\hline $\operatorname{Sex}(M: F)$ & $11: 2$ & $16: 6$ & n.s. \\
\hline Genotype (A:B:C) & $1: 1: 11$ & $0: 4: 18$ & n.s. \\
\hline HBeAg-positive & $10(77 \%)$ & $10(45 \%)$ & n.s. \\
\hline Combined therapy & $4(31 \%)$ & $10(45 \%)$ & n.s. \\
\hline PLT count $\left(\times 10^{4} / \mathrm{mm}^{3}\right)$ & $20.5 \pm 4.2$ & $22.3 \pm 2.2$ & n.s. \\
\hline $\operatorname{AST}(\mathrm{IU} / \mathrm{l})$ & $142.2 \pm 214.4$ & $69.9 \pm 69.5$ & n.s. \\
\hline ALT (IU/l) & $226.6 \pm 370.0$ & $91.2 \pm 99.8$ & n.s. \\
\hline T-Bil (mg/dl) & $0.82 \pm 0.52$ & $0.54 \pm 0.17$ & n.s. \\
\hline HBsAg (log IU/ml) & $4.01 \pm 0.62$ & $3.56 \pm 1.09$ & n.s. \\
\hline HBcrAg $(\log I U / m l)$ & $6.56 \pm 0.78$ & $5.30 \pm 1.66$ & $0.007^{\mathrm{a}}$ \\
\hline HBV-DNA (log copies/ml) & $8.00 \pm 1.60$ & $7.24 \pm 1.92$ & n.s. \\
\hline Increase in ALT at 12 weeks after starting & $8(62 \%)^{\mathrm{a}}$ & $3(14 \%)^{\mathrm{a}}$ & $0.014^{\mathrm{a}}$ \\
\hline
\end{tabular}

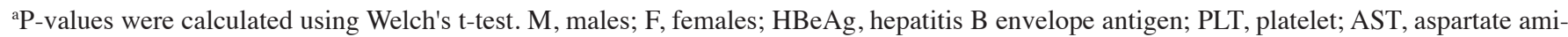
notransferase; ALT, alanine aminotransferase; T-Bil, total bilirubin; HBsAg, hepatitis B surface antigen; HBcrAg, HBV core-related antigen; HBV-DNA, hepatitis B virus DNA; n.s., not significant.

\section{A HBsAg $(\log \mathrm{IU} / \mathrm{ml})$}

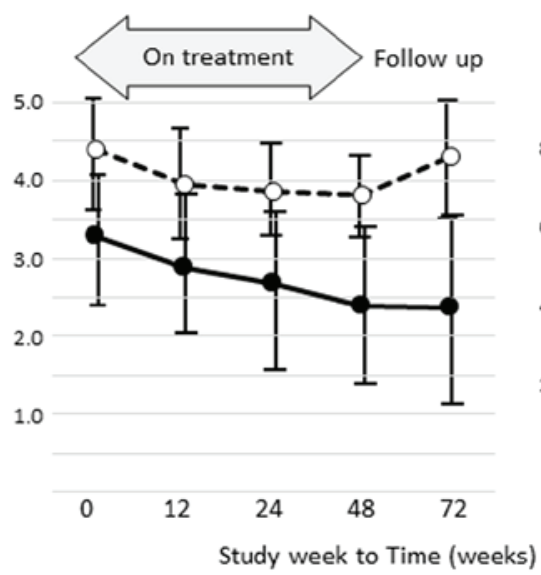

\section{B HBV-DNA (logcopies/ml)}

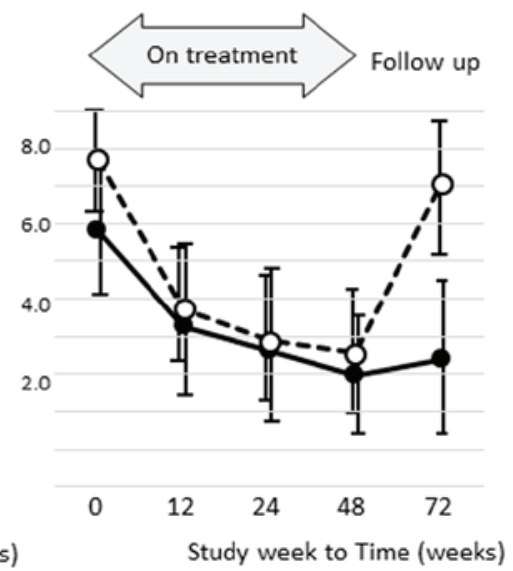

\section{C $\operatorname{ALT}(I U / I)$}

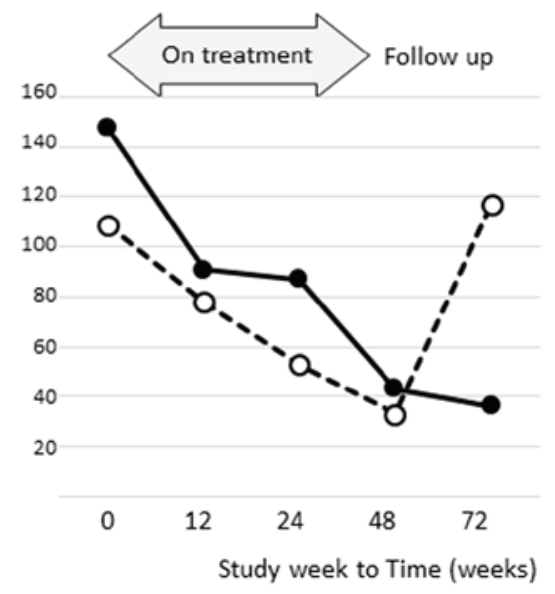

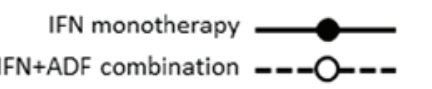

Figure 1. HBsAg titers, HBV-DNA levels, and ALT levels during and after therapy. (A) HBsAg titers, (B) HBV-DNA levels, and (C) ALT levels during and after treatment with IFN monotherapy or IFN and ADV combination therapy. HBV-DNA, hepatitis B virus DNA; ALT, alanine aminotransferase; IFN, interferon; ADV, adefovir.

patients who received combination therapy had re-increased at 24 weeks after treatment.

Factors associated with decreases in HBsAg titers during and after therapy. Although 13/35 (37\%) patients achieved a decrease in HBsAg of $>1 \log \mathrm{IU} / \mathrm{ml}$ from baseline to the end of treatment, $6(17 \%)$ patients experienced a relapse after therapy. In $7(20 \%)$ patients, the reduction in HBsAg was maintained until 24 weeks after treatment (Tables II and III). HBcrAg before therapy $(6.56 \pm 0.78$ vs. $5.30 \pm 1.66 \log \mathrm{IU} / \mathrm{ml}, \mathrm{P}<0.05)$ and the proportion of patients with an increase in ALT of $>2$ times from baseline ( 62 vs. $14 \%, \mathrm{P}<0.05$ ) were significantly greater in patients with a decrease in HBsAg of $>1 \log \mathrm{IU} / \mathrm{ml}$ at the end of treatment than in patients whose HBsAg did not decrease.

The mean ALT levels during and after therapy are shown in Fig. 2 according to the achievement of HBsAg reduction. Among patients without a decrease in $\mathrm{HBsAg}$ of $>1 \log \mathrm{IU} / \mathrm{ml}$ 
Table III. Factors associated with a decrease in the HBsAg titer of $>1 \log$ IU/ml at 24 weeks after therapy.

\begin{tabular}{|c|c|c|c|}
\hline Variables & $\begin{array}{c}\text { Patients with a } \\
\text { decrease in HBsAg }\end{array}$ & $\begin{array}{l}\text { Patients without a } \\
\text { decrease in } \mathrm{HBsAg}\end{array}$ & P-value \\
\hline $\mathrm{n}$ & $7(20 \%)$ & $28(80 \%)$ & \\
\hline Age (years) & $34.1 \pm 5.8$ & $37.4 \pm 9.0$ & n.s. \\
\hline $\operatorname{Sex}(M: F)$ & $6: 1$ & $21: 7$ & n.s. \\
\hline Genotype (A:B:C) & 1:0:6 & $0: 5: 23$ & n.s. \\
\hline HBeAg positive & $5(71 \%)$ & $15(54 \%)$ & n.s. \\
\hline Combined therapy & $1(14 \%)$ & $13(46 \%)$ & n.s. \\
\hline PLT count $\left(\times 10^{4} / \mathrm{mm}^{3}\right)$ & $20.8 \pm 4.0$ & $20.8 \pm 4.0$ & n.s. \\
\hline $\operatorname{AST}(\mathrm{IU} / \mathrm{l})$ & $179.3 \pm 257.9$ & $77.5 \pm 92.5$ & n.s. \\
\hline ALT (IU/1) & $332.1 \pm 476.0$ & $93.9 \pm 93.5$ & n.s. \\
\hline T-Bil (mg/dl) & $0.77 \pm 0.48$ & $0.77 \pm 0.48$ & n.s. \\
\hline HBsAg $(\log I U / m l)$ & $4.01 \pm 0.62$ & $3.56 \pm 1.09$ & n.s. \\
\hline HBcrAg $(\log \mathrm{IU} / \mathrm{ml})$ & $6.66 \pm 0.43$ & $5.42 \pm 1.69$ & $0.006^{\mathrm{a}}$ \\
\hline HBV-DNA (log copies/ml) & $7.62 \pm 1.82$ & $7.51 \pm 1.84$ & n.s. \\
\hline Increase in ALT at 12 weeks after starting & $5(71 \%)$ & $6(27 \%)$ & n.s. \\
\hline
\end{tabular}

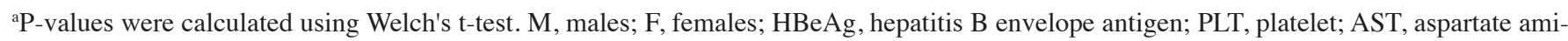
notransferase; ALT, alanine aminotransferase; T-Bil, total bilirubin; HBsAg, hepatitis B surface antigen; HBcrAg, HBV core-related antigen; HBV-DNA, hepatitis B virus DNA; n.s., not significant.

\section{A ALT level}

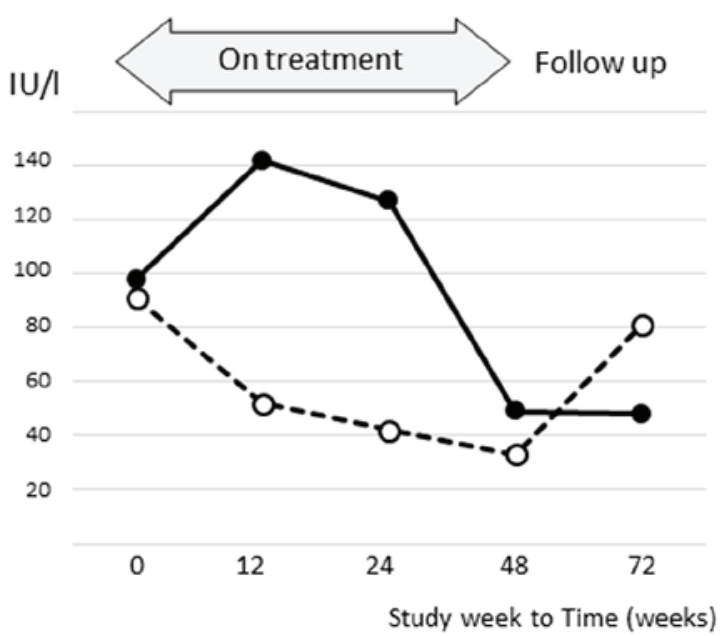

\section{B Fold-change relative to baseline}

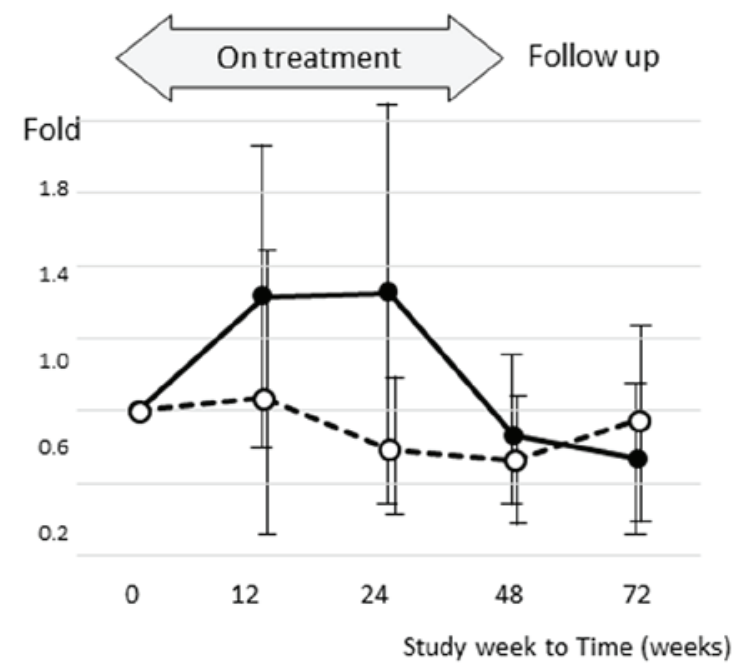

Patients with a decrease in $\mathrm{HBSAg}$ of $>1 \log \mathrm{IU} / \mathrm{mL}$

Patients without a decrease in $\mathrm{HBsAg}$ of $>1 \log \mathrm{IU} / \mathrm{ml}$

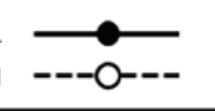

Figure 2. ALT levels compared with baseline during and after therapy. Actual (A) and fold-changes (B) in ALT levels during and after therapy in patients with or without a decrease in HBsAg titers of $>1 \log$ IU/ml. ALT levels increased markedly among patients without a decrease in HBsAg titers of $>1$ log IU/ml. ALT, alanine aminotransferase; $\mathrm{HBsAg}$, hepatitis B surface antigen.

at the end of therapy, the ALT level increased markedly after completing treatment.

\section{Discussion}

IFN is commonly used to treat $\mathrm{CHB}$, and studies have demonstrated its efficacy in HBeAg-negative patients in particular $(18,19)$. In the present study, HBe seroconversion was detected in just 2 (10\%) of $20 \mathrm{HBeAg-positive} \mathrm{subjects,}$ which indicates that IFN is less effective in $\mathrm{HBeAg}$-positive patients. The therapeutic efficacy of IFN is usually evaluated in terms of undetectable HBV-DNA and normalization of ALT levels at the end of treatment and at 24-96 weeks after treatment. In the present study, $16(45.7 \%)$ and $21(60 \%)$ patients had undetectable HBV-DNA and normalization of ALT levels, respectively, at the end of treatment. 
It is also well known that the efficacy of IFN differs among genotypes. In particular, the efficacy of IFN for treating $\mathrm{CHB}$ with genotype $\mathrm{A}$ and $\mathrm{D}$, which are prevalent in European countries, is much greater than that of $\mathrm{CHB}$ with genotypes $\mathrm{B}$ and $\mathrm{C}$, which are prevalent in Asian countries. In addition, its efficacy is less effective in genotype $\mathrm{C}$, which is spreading throughout Japan, than in genotype B, which is spreading in South China, Taiwan, and Thailand (20,21). Although none of the patients with genotype $\mathrm{C}$ achieved loss of HBsAg, one patient with genotype A had undetectable HBV-DNA and loss of HBsAg at the end of treatment. These findings suggest that the HBV genotype is associated with the efficacy of IFN.

$\mathrm{HBsAg}$ is produced from HBV/S protein and the HBsAg titer is correlated with the HBV viral quantity in the liver (22). Recently, HBsAg seronegativity has become a focus of the long-term goal of treatment, and the decrease in the HBsAg titer is an important factor for evaluating the outcome of antiviral therapy $(23,24)$. Of note, the decrease in the HBsAg titer during the early phase of IFN therapy is strongly associated with a sustained virological response (25). In the present study, a decrease in HBsAg of $>1 \log \mathrm{IU} / \mathrm{ml}$ was detected in $13(37 \%)$ patients at the end of therapy and in $7(20 \%)$ patients at 24 weeks after treatment. Thus, the HBsAg titer before starting treatment is an important factor associated with the outcome of antiviral therapy.

ADV is a NA of adenine and was reported to be effective in terms of reducing cccDNA $(26,27)$. The efficacy of IFN and ADV combination therapy was clearly demonstrated in a meta-analysis (10), which showed that the proportions of patients with undetectable HBV-DNA, HBeAg seroconversion, and normalization of ALT levels were significantly greater in patients who received combination therapy than in those who received IFN monotherapy (10). The present study also revealed that the proportion of patients with normalization of ALT was slightly greater in those who received combination therapy than in those who received monotherapy (71.4 vs. $66.7 \%$, respectively). However, the proportion of patients with undetectable HBV was lower in patients who received combination therapy (35.7 vs. $66.7 \%$, respectively) and the proportion of patients with an increase in ALT levels after therapy was higher in patients with combination therapy. These findings may be explained by the higher viral load before therapy and the greater proportion of HBeAg-positive patients among the group who received combination therapy.

The present study revealed that HBcrAg before treatment and on-treatment ALT flares were associated with the therapeutic efficacy. It was reported that on-treatment ALT flares were associated with the response to IFN, and are related to the immune response derived from IFN therapy $(24,28)$. In the present study, the proportion of patients with an ALT flare was similar between patients who received IFN monotherapy or combination therapy (33.3 vs. $35.7 \%$, respectively). $\mathrm{HBcrAg}$ is used mainly as a serum marker reflecting intrahepatic cccDNA $(29,30)$. In the present study, the HBcrAg titer before starting treatment was associated with the decrease in HBsAg at the end of treatment, although HBV-DNA was not associated with the reduction in HBsAg after treatment. These findings suggest that the HBcrAg titer is a superior serological marker for predicting the decrease in $\mathrm{HBsAg}$ elicited by IFN-based therapy.
In conclusion, the HBcrAg titer before starting treatment and the increase in ALT after treatment (host instruction flare) are important factors associated with the decrease in $\mathrm{HBs} \mathrm{Ag}$ after IFN-based therapy. The efficacy of IFN and ADV combination therapy was not apparent in terms of a decrease in HBsAg titers.

\section{References}

1. Lok AS and McMahon BJ: Chronic hepatitis B: Update 2009. Hepatology 50: 661-662, 2009.

2. European Association For The Study Of The Liver: EASL clinical practice guidelines: Management of chronic hepatitis B virus infection. J Hepatol 57: 167-185, 2012.

3. Liaw YF, Kao JH, Piratvisuth T, Chan HLY, Chien RN, Liu CJ, Gane E, Locarnini S, Lim SG, Han KH, et al: Asian-Pacific consensus statement on the management of chronic hepatitis $\mathrm{B}$ : A 2012 update. Hepatol Int 6: 531-561, 2012.

4. Marcellin P, Martinot-Peignoux M, Asselah T, Batrla R, Messinger D, Rothe V, Lau G and Liaw YF: Serum levels of Hepatitis B surface antigen predict severity of fibrosis in patients with E antigen-positive chronic Hepatitis B. Clin Gastroenterol Hepatol 13: 1532-9.e1, 2015.

5. Shouval D: Focus: Quantitative HBsAg measurement as a new surrogate marker for assessment of hepatic fibrosis in $\mathrm{HBeAg}+$ chronic hepatitis B. J Hepatol 58: 1063-1064, 2013

6. Kim GA, Lim YS, An J, Lee D, Shim JH, Kim KM, Lee HC, Chung YH, Lee YS and Suh DJ: HBsAg seroclearance after nucleoside analogue therapy in patients with chronic hepatitis B: Clinical outcomes and durability. Gut 63: 1325-1332, 2014.

7. Hynicka LM, Yunker N and Patel PH: A review of oral antiretroviral therapy for the treatment of chronic hepatitis B. Ann Pharmacother 44: 1271-1286, 2010.

8. Lam YF, Yuen MF, Seto WK and Lai CL: Current antiviral therapy of chronic hepatitis B: Efficacy and safety. Curr Hepat Rep 10: 235-243, 2011

9. Shi Y, Wu YH, Shu ZY, Zhang WJ, Yang J and Chen Z: Interferon and lamivudine combination therapy versus lamivudine monotherapy for hepatitis B e antigen-negative hepatitis B treatment: A meta-analysis of randomized controlled trials. Hepatobiliary Pancreat Dis Int 9: 462-472, 2010.

10. Huang R, Hao Y, Zhang J and Wu C: Interferon-alpha plus adefovir combination therapy versus interferon-alpha monotherapy for chronic hepatitis B treatment: A meta-analysis. Hepatol Res 43: 1040-1051, 2013.

11. Lau GK, Piratvisuth T, Luo KX, Marcellin P, Thongsawat S, Cooksley G, Gane E, Fried MW, Chow WC, Paik SW, et al: Peginterferon alfa-2a HBeAg-positive chronic Hepatitis B study group: Peginterferon Alfa-2a, lamivudine, and the combination for HBeAg-positive chronic hepatitis B. N Engl J Med 352: 2682-2695, 2005

12. Marcellin P, Lau GK, Bonino F, Farci P, Hadziyannis S, Jin R, Lu ZM, Piratvisuth T, Germanidis G, Yurdaydin C, et al: Peginterferon alfa-2a HBeAg-negative chronic hepatitis B study group: Peginterferon alfa-2a alone, lamivudine alone, and the two in combination in patients with $\mathrm{HBeAg-negative} \mathrm{chronic}$ hepatitis B. N Engl J Med 351: 1206-1217, 2004.

13. Marcellin P, Wursthorn K, Wedemeyer H, Chuang WL, Lau G, Avila C, Peng CY, Gane E, Lim SG, Fainboim H, et al: Telbivudine plus pegylated interferon alfa-2a in a randomized study in chronic hepatitis B is associated with an unexpected high rate of peripheral neuropathy. J Hepatol 62: 41-47, 2015.

14. Wursthorn K, Lutgehetmann M, Dandri M, Volz T, Buggisch P, Zollner B, Longerich T, Schirmacher P, Metzler F, Zankel M, et al: Peginterferon alpha-2b plus adefovir induce strong cccDNA decline and HBsAg reduction in patients with chronic hepatitis B. Hepatology 44: 675-684, 2006.

15. Takkenberg B, Terpstra V, Zaaijer H, Weegink C, Dijkgraaf M, Jansen P, Beld M and Reesink H: Intrahepatic response markers in chronic hepatitis B patients treated with peginterferon alpha-2a and adefovir. J Gastroenterol Hepatol 26: 1527-1535, 2011.

16. Takkenberg RB, Jansen L, de Niet A, Zaaijer HL, Weegink CJ, Terpstra V, Dijkgraaf MG, Molenkamp R, Jansen PL, Koot M, et al: Baseline hepatitis B surface antigen (HBsAg) as predictor of sustained HBsAg loss in chronic hepatitis B patients treated with pegylated interferon- $\alpha 2 \mathrm{a}$ and adefovir. Antivir Ther 18: 895-904, 2013. 
17. Xie QL, Zhu Y, Wu LH, Fu LL and Xiang Y: The efficacy and safety of entecavir and interferon combination therapy for chronic hepatitis B virus infection: A meta-analysis. PLoS One 10: e0132219, 2015.

18. Buster EH, Flink HJ, Cakaloglu Y, Simon K, Trojan J, Tabak F, So TM, Feinman SV, Mach T, Akarca US, et al: Sustained HBeAg and $\mathrm{HBs} A \mathrm{Ag}$ loss after long-term follow-up of $\mathrm{HBeAg}$-positive patients treated with peginterferon alpha-2b. Gastroenterology 135 : 459-467, 2008

19. Moucari R, Korevaar A, Lada O, Martinot-Peignoux M, Boyer N, Mackiewicz V, Dauvergne A, Cardoso AC, Asselah T, Nicolas-Chanoine $\mathrm{MH}$, et al: High rates of HBsAg seroconversion in $\mathrm{HBeAg}$-positive chronic hepatitis $\mathrm{B}$ patients responding to interferon: A long-term follow-up study. J Hepatol 50: 1084-1092, 2009.

20. Seo Y and Yano Y: Short- and long-term outcome of interferon therapy for chronic hepatitis B infection. World J Gastroenterol 20: 13284-13292, 2014.

21. Croagh CM, Desmond PV and Bell SJ: Genotypes and viral variants in chronic hepatitis B: A review of epidemiology and clinical relevance. World J Hepatol 7: 289-303, 2015.

22. Howard CR: The structure of hepatitis $B$ envelope and molecular variants of hepatitis B virus. J Viral Hepat 2: 165-170, 1995.

23. Höner Zu Siederdissen C and Cornberg M: The role of HBsAg levels in the current management of chronic HBV infection. Ann Gastroenterol 27: 105-112, 2014.

24. Brunetto MR, Moriconi F, Bonino F, Lau GK, Farci P, Yurdaydin C, Piratvisuth T, Luo K, Wang Y, Hadziyannis S, et al: Hepatitis $B$ virus surface antigen levels: A guide to sustained response to peginterferon alfa-2a in $\mathrm{HBeAg-negative} \mathrm{chronic} \mathrm{hepatitis} \mathrm{B.}$ Hepatology 49: 1141-1150, 2009.
25. Moucari R, Mackiewicz V, Lada O, Ripault MP, Castelnau C, Martinot-Peignoux M, Dauvergne A, Asselah T, Boyer N, Bedossa P, et al: Early serum HBsAg drop: A strong predictor of sustained virological response to pegylated interferon alfa- $2 \mathrm{a}$ in HBeAg-negative patients. Hepatology 49: 1151-1157, 2009.

26. Dando T and Plosker G: Adefovir dipivoxil: A review of its use in chronic hepatitis B. Drugs 63: 2215-2234, 2003.

27. Cheng PN, Liu WC, Tsai HW, Wu IC, Chang TT and Young KC: Association of intrahepatic cccDNA reduction with the improvement of liver histology in chronic hepatitis B patients receiving oral antiviral agents. J Med Virol 83: 602-607, 2011.

28. Hansen BE, Rijckborst V, Ter Borg MJ and Janssen HL: HBV DNA suppression in $\mathrm{HBeAg}$-positive chronic hepatitis B patients treated with peginterferon or placebo. J Med Virol 83: 1917-1923, 2011.

29. Wong DK, Tanaka Y, Lai CL, Mizokami M, Fung J and Yuen MF: Hepatitis B virus core-related antigens as markers for monitoring chronic hepatitis B infection. J Clin Microbiol 45: 3942-3947, 2007.

30. Suzuki F, Miyakoshi H, Kobayashi M and Kumada H: Correlation between serum hepatitis B virus core-related antigen and intrahepatic covalently closed circular DNA in chronic hepatitis B patients. J Med Virol 81: 27-33, 2009. 